\section{Loyalitas Kreativitas \\ Aldi Masyarakat Kreatif}

P-ISSN 2722-2101, E-ISSN 2722-4201

Program Studi Ekonomi Manajemen Universitas Pamulang

Jurnal LOKABMAS Kreatif Vol. 01, No. 01, Hal. 50 - 55

Email:jurnalkreatif.manajemen@gmail.com

\title{
PENGENALAN STRATEGI PEMASARAN PETERNAKAN AYAMGUNA MENINGKATKAN LABA PADA UKM DIDESA JUN REJO, JAWA TIMUR
}

\author{
Rahmi Andini, Arman Syah, Sinta Sulistiani, Yusran, Yeni Septiani \\ DosenEkonomi Fakultas Ekonomi Universitas Pamulang
}

Email dosen02062@unpam.ac.id, dosen02017@unpam.ac.id,dosen01876@unpam.ac.id dosen02331@unpam.ac.id,dosen00723@unpam.ac.id

\begin{abstract}
ABSTRAK
Salah satu dari tujuan Tridharma Perguruan Tinggi selain Pendidikan dan Penelitian adalah Pengabdian Kepada Masyarakat (PKM). Hal ini diatur dalam Pasal 20 dan 24 Undang-Undang. No. 20 Tahun 2003 tentang Sistem Pendidikan Nasional yang menyatakan bahwa adanya otonomi oleh Perguruan Tinggi, Penelitian Ilmiah dan Pengabdian Kepada Masyarakat. Sebagai pertanggungjawaban kami, maka dalam melaksanakan tugas tersebut telah kami susun laporan kegiatan pengabdian kepada masyarakat.

Dalam pelaksanaan Pengabdian Kepada Masyarakat ini, kami ingin membantu masyarakat dalam peningkatan laba para peternak ayam yang ada di Desa Junrejo.Hal ini dilakukan dengan memberikan bimbingan, pelatihan, pendampingan yang akhirnya hasil yang yang didapat dapat memberikan efek atau pengaruh yang lebih bail lagi. Selain itu pengelolaan sumber daya manusia yang seperti para peternak ayam khususnya di Desa Junrejo memerlukan peningkatan pengetahuan khususnya dalama hal strategi pemasaran ayam agar dapat lebih baik dalam meningkatkan laba usahanya.

Terimakasih atas dukungan Ketua Yayasan Sasmita Jaya, Rektor Universitas Pamulang, Dosen yang terlibat dan pihak-pihak yang telah membantu terselenggaranya Pengabdian Masyarakat. Harapan kami semoga kegiatan pengabdian ini akan bermanfaat bagi kita semua, khususnya kepada generasi muda harapan bangsa.
\end{abstract}

\section{Kata Kunci: StrategiPemasaran, UKM DesaJunrejo}

\section{ABSTRACT}

One of the goals of Higher Education Tridharma in addition to Education and Research is Community Service (PKM). This is regulated in Articles 20 and 24 of the Law. No. 20 of 2003 concerning the National Education System which states that there is autonomy by Universities, Scientific Research and Community Service. As our responsibility, in carrying out these tasks we have prepared reports on community service activities.

In the implementation of Community Service, we want to help the community in increasing the profits of chicken farmers in the village of Junrejo. This is done by providing guidance, training, and assistance, so that the results obtained can give even more effect or influence. In addition, the management of human resources such as chicken farmers, especially in the village of Junrejo requires increased knowledge, especially in terms of chicken marketing strategies in order to be better in increasing business profits. 


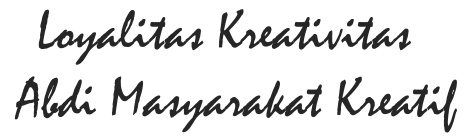

P-ISSN 2722-2101, E-ISSN 2722-4201

Program Studi Ekonomi Manajemen Universitas Pamulang Jurnal LOKABMAS Kreatif Vol. 01, No. 01, Hal. 50 - 55

Email:jurnalkreatif.manajemen@gmail.com

Thank you for the support of the Chairperson of the Sasmita Jaya Foundation, Chancellor of the University of Pamulang, the lecturers involved and those who have helped the implementation of Community Service. We hope that this community service will benefit us all, especially to the young generation of the nation's hopes.

\section{Keywords: Marketing Strategy, Junrejo Village UKM}

\section{PENDAHULUAN}

Peternakan merupakan suatu kegiatan mengembangbiakkan dan membudidayakan hewan ternak untuk mendapatkan manfaat dan hasil dari kegiatan tersebut. Pengertian peternakan tidak terbatas pada pemeliharaan saja, namun terletak pada tujuan yang ditetapkan. Tujuan peternakan adalah mencari keuntungan dengan penerapan prinsip-prinsip manajemen pada faktor-faktor produksi yang telah dikombinasikan secara optimal.

Seiring dengan pertambahan penduduk yang diikuti dengan meningkatnya kebutuhan akan produk dan jasa khususnya kebutuhan pokok masyarakat seperti ayam. Usaha peternakan ayam pada saat ini sudah begitu dikenal di kalangan masyarakat, hal ini tentunya merupakan hal yang menggembirakan karena selain pendapatan perkapita meningkat, kebutuhan akan protein hewani juga tercukupi. Protein merupakan komponen kimia terpenting yang ada di dalam daging untuk proses pertumbuhan perkembangan dan pemeliharaan kesehatan.

Kegiatan agribisnis di Indonesia sudah ada sejak sebelum adanya pembangunan jangka panjang (PJP) I dimana ujung tombak pembangunan agribisnis adalah usaha tani/pertanian dan jpembangunan jangka panjang II denga ujung tombaknya yaitu agroindustry (pengolahan) teruatama makanan (Firdaus, 2009). Salah satu peluang usaha yang tidak pernah ada habisnya adalah peluang usaha yang berkaitandengan makanan. Peluang tersebut tersebar mulai dari penyediaan sejak bahan baku hingga produk jadinya yaitu makanan. Salah satu komoditas yang paling diminati oleh para wirausaha dari dulu hingga kini adalah bisnis ayam ras pedaging. Ayam ras pedaging relatif mudah diterima, biak dari faktor rasa, kecepatan produksi dan biaya. Daging ayam ras pedaging (broiler) juga hamper tidak ada tantangan dari sosial maupun agama atas produk ini. Sehingga peluang usaha budidaya ayam ras pedaging sangat luas dan layak dilakukan (Alex, 2014).

Meningkatnya usaha peternakan ayam akan menambah persoalan-persoalan baru yang dan perlu diselesaikan. Masalah-masalah tersebut berhubungan dengan berbagai aspek manajemen yang meliputi penyediaan pakan, sistem perkandangan, pencegahan penyakit dan pemasaran produk.

Tuntutan kompetisi antar produk sudah semakin mendesak, terutama dalam merebut pangsa pasar, tingkat kualitas produk yang sesuai dengan tuntutan pelayanan, terutama pada kalangan menengah atas harus terpenuhi. Derasnya arus informasi dapat mempengaruhi perilaku konsumen terhadap suatu produk tertentu. Media massa cetak serta elektronik dapat memberi informasi terbaru dalam waktu singkat dan memberikan dampak bagi perilaku konsumen khususnya dalam perilaku konsumsi.

Istilah pemasaran dan tata niaga di negara kita telah dipakai seccara silih berganti dan mempunyai batasan yang sama, yaitu kegiatan yang berfungsi menyalurkan produk dari produsen sampai ke konsumen akhir. Dari batasan tersebut terlihat bahwa masalah yang dihadapi dalam pemasaran ayam ini mulai dari ayam keluar kandang hingga tiba ke tangan konsumen akhir, termasuk di dalamnya segala aturan main, pelaku bisnis dijalur pemasaran dan aspek-aspek lainnya.

Pemasaran yang dilaksanakan dengan baik adalah salah satu faktor pendukung berhasilnya suatu usaha peternakan ayam ras pedaging. Menurut Gito Sudarmo (2008) pemasaran dapat diartikan sebagai suatu kegiatan yang mengusahakan agar produk yang dipasarkan itu dapat diterima dan disenangi pasar serta dapat memenuhi kebutuhan pasar. 


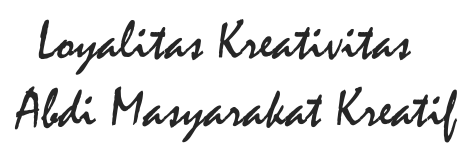

Setiap usaha yang didirikan pasti mempunyai tujuan utama, yaitu mencapai keuntungan tertentu, pertumbuhan perusahaan atau peningkatan pangsa pasar. Dalam pandangan konsep pasar, tujuan perusahaan ini dicapai melalui keputusan konsumen. Keputusan konsumen diperoleh seterlah kebutuhan dan keinginan konsumen dipenuhi melalui kegiatan pemasaran yang terpadu.

Menurut firdaus (2009), pemasaran merupakan salah satu kegiatan pokok yang harus dilakukan oleh para pengusaha termasuk pengusaha tani (agribusinessman) dalam usahanya untuk mempertahankan kelangsungan hidupnya (survival), untuk mendapatkan laba dan untuk berkembang. Selain itu pemasaran juga merupakan suatu proses sosial dan manajerial dimana individu dan kelompok mendapatkan kebutuhan dan keinginan mereka dengan menciptakan, menawarkan dan bertukar sesuatu yang bernilai satu sama lain.

Secara lebih mudah menurut Marwoto H.B. (2014) pengertian pemasaran adalah sistem keseluruhan dari kegiatan bisnis yang ditujukan untuk merencanakan dan mendistribusikan produk atau jasa kepada pembeli serta perusahaan untuk memuasakan keinginan dan kebutuhan pembeli yang ada dan pembeli yang potensial.

Kegiatan pemasaran merupakan faktor penting yang akan menentukan keberhasilan usaha suatu perusahaan. Salah satu unsur dalam kegiatan pemasaran tersebut adalah bauran pemasaran (marketing mix) yang terdiri dari $4 \mathrm{P}$ : product, price, place dan promotion. Perusahaan harus mampu menghasilkan produk yang berkualitas, menetapkan harga dengan tepat dan melakukan promosi yang efektif. Disamping itu penentuan salurna distribusi yang akan dipakai perusahaan sangatlah penting. Banyaknya alternatif saluran distribusi menuntut perusahaan untuk lebih selektif dalam memilih saluran yang akan digunakan.

Dengan saluran distribusi yang tepat maka keuntungan yang diperoleh perusahaan yang dalam hal ini adalah peternak ayam akan semakin besar. Kesalahan yang dilakukan perusahaan dalam pemilihan saluran distribusi dapat menghambat kelancaran aliran produk dari produsen ke konsumen yang nantinya akan merugikan perusahaan itu sendiri.

Dengan penerapan sistem bauran pemasaran yang teroganisir, maka perusahaan akan lebih mudah untuk memenuhi tujuan dari pemasaran yaitu mampu bersaing dan menembus pasaran yang luas sehingga pada akhirnya menaikkan volume penjualan dan laba.

\section{RUMUSAN MASALAH}

Dengan mempertimbangkan latar belakang yang telah diutarakan diatas kami berinisiatif untuk membentuk pengabdian masyarakat dengan perumusan masalah pada PKM ini adalah:Bagaimana penerapan strategi pemasaran yang baik pada peternakan ayam guna meningkatkan laba? Serta faktor-faktor apa saja yang mempengaruhi peternak telur dalam memasarkan ayamnya?

\section{TUJUAN PELAKSANAAN}

1. Untuk menerapkan strategi pemasaran yang baik pada peternakan ayam guna meningkatkan laba;

2. Untuk mengetahui faktor-faktor yang memperngaruhi peternak telur dalam memasarkan ayamnya;

\section{TINJAUAN PUSTAKA}

\section{Ternak Ayam}

Ayam broiler merupakan salah satu komoditi unggas yang memberikan kontribusi besar dalam memenuhi kebutuhan hewani masayarakat Indonesia (Umam dkk, 2015). Kebutuhan daging ayam meningkat setiap tahunnya karena harga daging ayam yang terjangkau bagi seluruh kalangan masyarakat. Keunggulan ayam broiler adalah Teknik pemeliharaannya yang terbilang cepat sekitar 30 hari sudah siap panen. Penampilan ayam broiler yang baik dapat dilihat dari system intensif modern yang memakai bibit unggul, pemberian pakan yang unggul dana spek kesehatan yang bagus (Nuriyasa, 2003)

\section{Pemasaran}

Menurut Kotler (2000), mendefinisikan pemasaran sebagai suatu rangkaian tujuan dan sasaran, kebijakan dan aturan yang menjadi arah kepada usaha-usaha pemasaran perusahaan 
dalam menghadapi lingkungan dan keadaan pesaing yang selalu berbeda. Pemasaran merupakan suatu proses sosial manajerial yang di dalamnya individu dan kelompok mendapatkan apa yang mereka butuhkan dan inginkan dengan menciptakan, menawarkan dan mempertukarkan produk yang bernilai dengan pihak lain. Konsep ini yang mendasari definisi pemasaran diantaranya: kebutuhan (needs), keinginan (want), dan permintaan (demands).

Konsep pemasaran terdiri dari empat pilar yaitu pasar sasaran, kebutuhan pelanggan, pemasaran terpadu atau terintegrasi, dan kemampuan menghasilkan laba. Perusahaan akan berhasil secara gemilang bila mereka secara cermat memilih sejumlah pasar sasarannya dan mempersiapkan program pemasaran yang dirancang sesuai dengan kebutuhan pelanggan untuk masing-masing pasar yang dituju. Bila di suatu perusahaan bekerjasama untuk melayani kebutuhan pelanggan, maka akan dihasilkan pemasaran terpadu, sedang tujuan terakhir konsep pemasaran membantu perusahaan untuk mencapai tujuan perusahaan dengan menghasilkan laba melalui kepuasan pelanggan (Tjiptono, 2001).

Konsep pemasaran mempunyai perspektif dari luar kedalam, yang artinya konsep ini dimulai dari pasar yang didefinisikan dengan baik, berfokus pada kebutuhan pelanggan, dan menghasilkan laba dengan memuaskan pelanggan (Kotler, 2005). Pemasaran dapat diuraikan sebagai menetapkan, mengantisipasi, menciptakan, dan memenuhi kebutuhan serta keinginan pelangganakan produk dan jasa. Menurut Kotler (2004), salah satu konsep utama dalam pemasaran modern merupakan bauran pemasaran. Manajemen pemasaran adalah proses menganalisis, merencanakan, mengkoordinasikan, dan mengendalikan program-program yang mencaku ppengkonsepan, penetapan harga, promosi dan distribusi dari produk, jasa dan gagasan yang dirancang untuk menciptakan serta memelihara pertukaran yang menguntungkan dengan pasar sasaran untuk mencapai tujuan perusahaan (Boyd, 2000).

Sedangkan menurut Kotler (2000), manajemen pemasaran adalah proses perencanaan dan pelaksanaan pemikiran, penetapan harga, promosi, serta penyaluran gagasan, barang dan jasa untuk menciptakan pertukaran yang memenuhi sasaran individu dan organisasi. Kedua pengertian tersebut merumuskan suatu konsep tindakan yang dapat dilaksanakan oleh manajemen pemasaran perusahaan agar dapat melakukan aktivitas pemasaran yang baik dan tepat sasaran, serta menekankan bahwa semua aktivitas pemasaran adalah untuk menciptakan dan memelihara pertukaran yang menguntungkan dengan pasarsasaran untuk mencapai tujuan perusahaan. Pemasaran juga dapat diartikan sebagai kegiatan yang dilakukan untuk mengusahakan agar suatu produk tersebut dapat diterima di pasar dan disenangi pasar (Amalia, 2013).

\section{a. Product}

Produk adalah suatu sifat yang kompleks baik yang dapat diraba maupun tidak dapat diraba termasuk bungkus, warna, harga prestice, perusahaan dan pengecer, pelayanan perusahaan dan pengecer yang diterima oleh pembeli untuk memuaskan keinginan dan kebutuhan pembeli (Swastha, 1996). Hal yang paling penting untuk diingat adalah barang atau jasa harus dapat memuaskan kebutuhan pelanggan (Budiwati, 2012).

\section{b. Place}

Tempat atau identik dengan saluran distribusi adalah salah satu variabel yang penting untuk meningkatkan volume penjualan dan mengacu pada suatu tempat bagi pelanggan untuk lebih mudah mengaksesnya dan mendapatkannya. Saluran distribusi serangkaian organisasi yang saling tergantung dan terlibat dalam proses untuk menjadikan suatu barang atau jasa siap untuk digunakan atau dikonsumsi (Kotler, 1997). Saluran distribusi merupakan suatu kelompok perantara yang berhubungan erat satu sama lain dan yang menyalurkan produk-produk ke pembeli (Winardi, 1992). Saluran pemasaran merupakan suatu kelompok perantara yang berhubungan erat satu sama lain dan yang menyalurkan produk-produk dari produsen ke konsumen (Winardi, 1992). Saluran pemasaran pada peternakan ayam ras maupun buras terbilang panjang mulai dari pedagang 
Loyalitas Kreativitas
Aldi Masyarakat Kreatif
P-ISSN 2722-2101, E-ISSN 2722-4201

Program Studi Ekonomi Manajemen Universitas Pamulang

Jurnal LOKABMAS Kreatif Vol. 01, No. 01, Hal. 50 - 55

Email:jurnalkreatif.manajemen@gmail.com pengumpul, pangkalan pemotong ayam, pedagang pengecer kemudian ke konsumen. Saluran pemasaran yang panjang perlu diperkecil agar biaya distribusi yang dikeluarkan pun lebih kecil (Amalia, 2013).

Margin pemasaran adalah perbedaan harga yang dibayarkan kepada peternak dengan harga jual kepada pedagang pengecer dan konsumen dalam saluran pemasaran dengan komoditi yang sama (Ali, 2014). Besaran margin pemasaran tergantung pada perubahan biaya pemasaran, keuntungan pedagang perantara, harga konsumen akhir dan harga yang diterima produsen. Harga margin pemasaran juga tergantung pada jauh dekatnya jarak daerah antara konsumen dan produsen serta sifat produk juga menjadi pertimbangan besarnya margin pemasaran (Purmantono, 1993).

\section{c. Price}

Harga adalah sejumlah uang yang harus dikeluarkan konsumen untuk mendapatkan suatu produk atau jasa. Harga juga merupakan pesan yang menunjukan bagaimana suatu brand memposisikan dirinya di dalam pasar (Kotler, 2000). Harga merupakan satuan moneter atau ukuran lainnya (termasuk barang dan jasa lainnya) yang ditukarkan agar memperoleh hak kepemilikan atau penggunaan suatu barang atau jasa.

\section{d. Promotion}

Promosi adalah suatu cara khusus dari iklan pribadi, promosi penjualan dan hubungan masyarakat yang dipergunakan perusahaan untuk tujuan mempromoskan iklan dan pemasarnya (Kotler, 2004). Promosi adalah kombinasi strategi yang baik dari variable periklanan, personal selling, dan alat promosilainnya yang direncanakan untuk mencapai suatu tujuan program penjualan (Swastha, 2000).

\section{HASIL DAN PEMBAHASAN}

Pengabdian Masyarakat (PKM) Universitas Pamulang yang dilakukan oleh dosen-dosen program studi Manajemen telah berjalan dengan lancar dan mendapat sambutan hangat dari tempat pelaksanaan kegiatan ini yaitu di Desa Jun Rejo. JawaTimur.

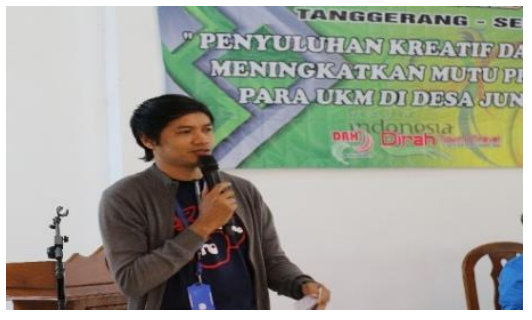

Harapan kami dengan pengabdian ini dapat membuka wawasan masyarakat yang diperoleh adalah bertambahnya keilmuan bagi para Para Masyarakat tentang peningkatanlabapadapeternakayamdanIlmu yang diperoleh pada Pengabdian Masyarakat kali ini diharapkan mampu memberikan semangat baru bagi kita dalam menyampaikan materi dan motivasi serta berkontribusi bagi generasi muda, baik dilingkungan sekolah, kampus dan keluarga.

\section{KESIMPULAN DAN SARAN}

\section{Kesimpulan}

Dalam pelaksanaan Pengabdian Kepada Masyarakat ini, kami ingin membantu masyarakat dalam peningkatan laba para peternak ayam yang ada di Desa Junrejo.Hal ini dilakukan dengan memberikan bimbingan, pelatihan, pendampingan yang akhirnya hasil yang yang didapat dapat memberikan efek atau pengaruh yang lebih bail lagi. Selain itu pengelolaan sumber daya manusia yang seperti para peternak ayam khususnya di Desa Jun rejo memerlukan peningkatan pengetahuan khususnya dalam ahal strategi pemasaran ayam agar dapat lebih baik dalam meningkatkan laba usahanya.

Dalam rangka meningkatkan laba para peternak ayam yang tergabung dalam UKM di Desa Jun rejo maka diperlukan strategi dalam pemasaran produk mereka yaitu ayam ternak. Strategi yang sesuai adalah dengan menjual produk mereka yang memberikan efektifitas serta efisiensi dalam hal harga serta margin yang didapat.

\section{Saran}




\section{Loyalitas Kreativitas \\ Aldi Masyarakat Kreatif}

P-ISSN 2722-2101, E-ISSN 2722-4201

Program Studi Ekonomi Manajemen Universitas Pamulang Jurnal LOKABMAS Kreatif Vol. 01, No. 01, Hal. 50 - 55

Email:jurnalkreatif.manajemen@gmail.com
Untuk pemasaran ternak ayam yang lebih efisien, maka disarankan kepada para pelaku pemasaran untuk memilih dan menentukan saluran pemasaran yang lebih efisien dan menguntungkan,sehingga memberikan keuntungan kepada semua pihak yang terlibat dalam system pemasaran ternak ayam.

Saran terhadap instansi atau pemerintah setempat adalah sebaiknya dilakukan penyuluhan kepada peternak ayam buras di Desa Junrejo tentang bagaimana strategi pemasaran yang layak di lakukan oleh peternak sehingga memberikan keuntungan yang besar serta melakukan kegiatan penyuluhan kepada para peternak ayam tentang bagaimana mengatasi berbagai masalah khususnya mengenai wabah flu burung

\section{DAFTAR PUSTAKA}

Assauri, Sofyan.1999. Manajemen Produksi dan Operasi. Lembaga Penerbit Fakultas Ekonomi. Universitas Ekonomi. Jakarta.

David, Fred R. 2006. Manajemen Strategis: Konsep, Edisi 10. Salemba Empat. Jakarta.

Kotler. Philip. 1997. Manajemen Pemasaran. Terjemahan. Jilid 1. Prehalindo. Jakarta.

Suliyanto. 2010. Studi Kelayakan Bisnis. Andi. Yogyakarta.

Stanton. Wiliam. J. 1984. Fundamentals of Marketing. McGraw Hill. New York.

Pasaribu, V. L. D., Agrasadya, A., Shabrina,

N., \& Krisnaldy, K. (2020). MENJADI

ENTERPRENEUR MUDA YANG MEMILIKI

JIWA LEADERSHIP UNTUK

MENGHADAPI MASA DEPAN. Abdi

Laksana, 1(1)

Pasaribu, V. L. D., Elburdah, R. P., Sudarso, E., \& Fauziah, G. (2020). PENGGUNAAN MANAJEMEN WAKTU TERHADAP PENINGKATAN PRESTASI BELAJAR DI SMP ARAISIYAH. Jurnal ABDIMAS, 1(1)
Pasaribu, V. L. D., Susanti, F., \& Hartuti, E. T. K. (2019). MEMOTIVASI SISWA DAN SISWI SMK LETRIS INDONESIA DI DALAM MENENTUKAN PILIHAN UNTUK MELANJUTKAN PENDIDIKAN ATAU BEKERJA SETELAH LULUS SEKOLAH. Jurnal Pengabdian Dharma Laksana, 1(2), 161-172.
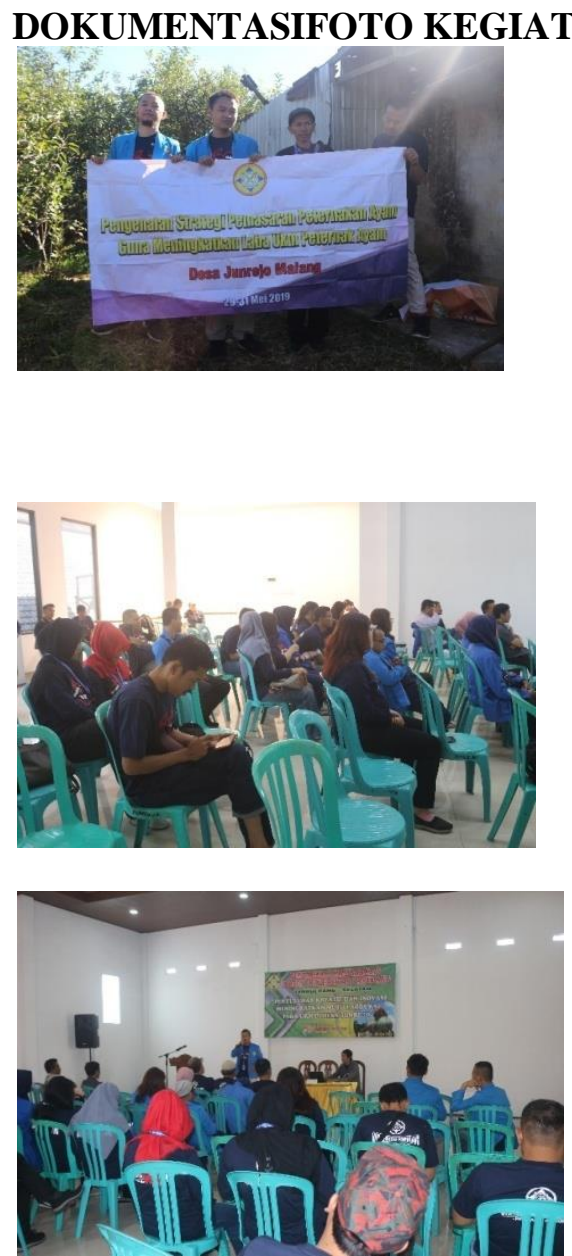